\title{
Problematika aplikace profesních hodnot v sociální práci ${ }^{1}$
}

\section{Monika Flídrová}

Problematika hodnot sociální práce je aktuálně častým tématem studií, ve kterých jsou hodnoty diskutovány mnohdy ve snaze ukotvit profesní identitu. ${ }^{2}$ Tato úzká souvislost mezi hodnotami a profesní identitou vyplývá z již obecných daností, tj. že se aplikované hodnoty sociální práce spolupodílejí na vytváření stabilní identity profese, protože jsou skrze jejich uskutečňování naplňovány principy, cíle profese i cíle jednotlivých organizací, které z hodnot vycházejí. Hodnoty mají vliv na výběr metod, utvářejí vztahy především mezi pracovníkem a klientem nebo také vymezují poslání profese. Proto srozumitelné definování hodnot přispívá $\mathrm{k}$ větší transparentnosti profese pro její klienty i širokou veřejnost, která si tímto dokáže snáze představit smysl a úkol práce. "Sociální pracovník tedy nepotřebuje jen znalosti a dovednosti, proč a jak dělat sociální práci, ale i hodnoty, aby se při výkonu sociální práce mohl správně rozhodovat. Pokud by platil hodnotový relativismus, sociální práce by neměla smysl. Když vše může být správné i nesprávné, dobré i špatné a záleží jen na úhlu pohledu, východiscích, kulturních stereotypech, pak nemá smysl snažit se o změnu nějaké životní situace. Pak není třeba pomáhat druhému, aby se jeho život stal (opět) kvalitnějším nebo si udržel co nejvyšší kvalitu. “"

Profesní hodnoty sociální práce jsou proto definovány v etických kodexech jednotlivých společností či organizacís (např. v prohlášeních o poslání - tzv. mission statement), ale i u mnohých autorů. ${ }^{6}$ Paradoxně je nám tak nakonec představena široká škála profesních hodnot. Př́činou vzniklé plurality v definování konkrétních hodnot může být mnoho faktorů, z nichž nyní uved'me např. problematiku vymezení pojmu hodnota, nevymezené hranice profesní etiky a s tím souvisejícíi chybějící jasnou představu o tom, jaké hodnoty mají být zahrnuty do sociální práce. Dostáváme se do „začarovaného kruhu“, který směřuje (1) od problematiky profesních hodnot (2) k nejasné profesní identitě (3) a k nedostatečnému aplikování hodnot v praxi. (4) Tím dochází $\mathrm{k}$ nenaplňování podstaty profese, (5) která by nás měla vést $\mathrm{k}$ zamyšlení nad definováním základních profesních hodnot. Hlavním záměrem této studie je tedy především poukázat na nesnadnou aplikaci hodnot $\mathrm{v}$ praxi popisem některých př́ččin či bariér, které zabraňují sociálním pracovníkům aplikovat profesní hodnoty $\mathrm{v}$ praxi. Ve studii vycházíme $\mathrm{z}$ aktuálních diskuzí o hodnotách v etice sociální

\footnotetext{
1 Tato studie vznikla v rámci projektu výzkumu Grantové agentury Jihočeské univerzity 117/2013/H - Pojetí kvality sociální práce v souvislosti se sebedefinováním sociálního pracovníka a jeho pomáhající profese.

2 Srov. např. Monika FLÍDROVÁ - Michal OPATRNÝ, Role hodnot v identitě sociální práce, Sociální práce / Sociálna práca 2/2014, s. $118-126$.

3 Srov. tamtéž, s. 123-125; Mirka NEČASOVÁ, Profesní etika, in: Metody a řízení sociální práce, ed. Oldřich MATOUŠEK, Praha: Portál, 2013, s. 32.

4 Monika FLÍDROVÁ - Michal OPATRNÝ, Role hodnot v identitě sociální práce, s. 122.

5 Srov. napr. (C) British Association of Social Workers, The Code of Ethics for Social Work (online), dostupné na: http://cdn.basw. co.uk/upload/basw_112315-7.pdf, citováno dne 10.12. 2014.

6 Srov. např. Sarah BANKS, The social work value base: human rights and social justice in talk and action, in: The Value Base of Social Work and Social Care: An Active Learning Handbook, ed. Adam BERNARD - Nigel HORNER, Berkshire: Open University Press, 2008, s. 31. Z německého prostředí uved'mě např. Silvii Staub-Bernasconi, která hodnotový koncept sociální práce zakládá na lidských právech, přičemž vychází nikoli z hodnot, ale z univerzálních potřeb člověka. Srov. Silvia STAUB-BERNASCONI, Soziale Arbeit als Handlungswissenschaft: systemtheoretische Grundlagen und professionelle Praxis - ein Lebrbuch, Bern; Stuttgart; Wien: Haupt, 2007, s. 192-193.
} 
práce, proto i dále jmenované př́činy nesnadné aplikace hodnot zdaleka nenabízejí čtenáři jejich úplný výčet. Cílem je spíše přispět k širokospektré diskuzi zabývající se významem a problematikou hodnot v sociální práci. ${ }^{7}$

\section{Znalost profesních hodnot}

Vrámci projektuč.117/2013/H na Katedře etiky, psychologie a charitativní práce na Teologické fakultě Jihočeské univerzity, zkoumajícího „pojetí kvality sociální práce v souvislosti se sebedefinováním sociálního pracovníka a jeho pomáhající profese“, byl v roce 2013 uskutečněn předvýzkum kvalitativní metodou strukturovaného rozhovoru s otevřenými otázkami, jehož cílem bylo zmapovat subjektivní pohled sociálních pracovníků na sociální práci, její kvalitu a postavení ve společnosti. Výzkumnou jednotku tvořilo 25 sociálních pracovníků vybraných na základě demografických údajů dle metody výběru, ${ }^{8}$ kteří splňovali podmínku vzdělání podle zákona 108/2006 Sb. ${ }^{9}$ a měli minimálně dva roky praxe v oboru. Jedna z otázek výzkumu zjištovala, „které hodnoty se spojují s profesí sociálního pracovníka“.

Zatímco Mezinárodní federace sociálních pracovníků začlenila do Mezinárodního etického kodexu hodnoty jako důstojnost, lidská práva a sociální spravedlnost ${ }^{10}$ nebo Společnost sociálních pracovníků v ČR uvedla v Etickém kodexu společnosti sociálních pracovníků ČR demokracii, lidská práva a sociální spravedlnost (přičemž oba kodexy se zaměřují také na odbornost), ${ }^{11}$ nejčastější udávanou „hodnotou“ dle sociálních pracovníků (respondentů výzkumu) byla empatie. Tato „hodnota“ byla uvedena patnáctkrát (uvedlo ji tedy $3 / 5$ respondentů). Jiné „hodnoty“ byly zmiňované zřídka. Pouze šest pracovníků uvedlo odbornost. Pětkrát se ve výčtu respondentů objevily hodnoty lidství, vztah, služba i altruismus. Zásadní hodnoty etických kodexů nebyly téměř jmenovány. Hodnotu důstojnosti můžeme sice obecně zařadit k hodnotě lidství nebo k úctě, jako samotná se však u žádného z respondentů ve výčtu neobjevila. Lidská práva uvedl jediný sociální pracovník, jiní tři alespoň zmínili rovnost či nediskriminaci, tedy jednotlivé principy lidských práv. Pouze jeden respondent uvedl hodnotu sociální spravedlnosti, která je primárně uznávanou hodnotou sociální práce nejen v kodexech. Sociální pracovníci se naopak často zaměřovali na „hodnoty“, které popisují charakter pracovníka. Podle nich by měl být sociální pracovník zralou osobností, což spojovali s důvěryhodností; měl by být otevřený, ke klientům vstříný či poctivý aj. Hodnotu solidarity uvedli pouze 2 sociální pracovníci z 25, tato četnost byla stejná jako u jimi jmenované hodnoty rodiny či pravdy. ${ }^{12}$

\footnotetext{
7 S. Banks označuje právě také nedostatečnou komunikaci mezi různými typy pracovníků i organizací za jednu z bariér v aplikování profesních hodnot v praxi. Srov. Sarah BANKS, The social work value base, s. 32 .

8 Respondenti byli vybráni metodou nenáhodného záměrného výběru (Srov. Jan HENDL, Kvalitativní výzkum, Praha: Portál, 2005, s. 52) ze všech krajů České republiky, typů obcí (obec, město, velkoměsto) i sociálních služeb (ambulantní, pobytové, terénní, úřad). Výběr zohledňoval tři aspekty: podíl jednotlivých typů zařízení ve státě, podíl jednotlivých zařízení podle počtu obyvatel čtrnácti krajů a v rámci nich podle velikosti místa bydliště.

9 Srov. Zákon č. 108/2006 Sb., o sociálních službách, $\mathbb{\int} 110$.

10 Srov. (C) Společnost sociálních pracovníků ČR, Etika sociálnípráce - principy (on-line), dostupné na: http://socialnipracovnici. cz/public/upload/image/mezinarodni_eticky_kodex.pdf, citováno dne 12.12. 2014.

11 Srov. (C) Společnost sociálních pracovníků ČR, Etický kodex společnosti sociálních pracovníki ČR (on-line), dostupné na: http://socialnipracovnici.cz/public/upload/image/eticky_kodex_sspcr.pdf, citováno dne 12.12. 2014.

12 Podrobnější zpracování výzkumné otázky viz Monika FLÍDROVÁ, Sociální práce jako práce ř́żená profesními bodnotami (diplomová práce), České Budějovice: Teologická fakulta Jihočeské univerzity, 2014.
} 
Jmenované profesní hodnoty sociálních pracovníků zúčastněných na výzkumu přispívají k otevření tématu problematiky aplikace profesních hodnot a hledání příčin, které se jeví jako multifaktoriální. Z vyhodnocení odpovědí můžeme sledovat především (1) neznalost hodnot, které jsou uvedeny $\mathrm{v}$ kodexech či profesními odborníky, ale také (2) pojetí pojmu hodnota spíše v kontextu osobnostních vlastností a kompetencí (především pak komunikačních dovedností), které jsou potřebné pro vykonávání profese (tj. neporozumění pojmu hodnota) a (3) významný vliv osobních hodnot (např. láska, pravda) na utváření pojetí profese. Proto osobní hodnoty v konfliktu s profesními hodnotami mohou být jednou $\mathrm{z}$ príćíin neaplikování hodnot $\mathrm{v}$ praxi (viz bod 4). Rovněž se můžeme ptát, zda př́stup mnohých sociálních pracovníků není př́liš laxní, zda dostatečně zohledňují ve své praxi poslání a organizační cíle či zda jejich jednání a postupy nejsou motivovány naopak spíše filantropií, bez úsilí o profesionální pojetí sociální práce.

\section{Nejednoznačná definice pojmu}

Jako jednu z hlavních prričin neznalosti profesních hodnot sociální práce i celkově hodnotového pluralismu můžeme jmenovat nesrozumitelnost pojmu hodnota. Přestože hodnoty patři $\mathrm{v}$ humanitních vědách $\mathrm{k}$ velice častým pojmům, nejsou jednoznačně definovány ani v psychologii, filosofii či sociologii. ${ }^{13}$ Důsledkem toho je vznik mnoha definic a členění hodnot, které vedou k jejich velice nejednoznačnému pojetí. Proto také definování pojmu hodnota $\mathrm{v}$ kontextu sociální práce představuje prozatím primární problém profesní etiky. ${ }^{14}$ Řečeno naopak, formulace pojetí hodnoty v kontextu sociální práce by umožnila profesní hodnoty jednoznačněji definovat, následně je interiorizovat a aplikovat do praxe.

Nejednoznačnost pojmu se projevuje také v Mezinárodním etickém kodexu, ve kterém je používán pojem „princip“ namísto „hodnoty“. Obecně se v literatuře často setkáme s těmito dvěma pojmy jako synonymy. Jenže $\mathrm{v}$ kodexu jsou tyto principy rozpracovány do dalších principů. Rovněž i lidská práva mají v kodexu dvojí pozici: Nejprve se vyskytují v pozici základní jmenované hodnoty a následně „vyplývají" $\mathrm{z}$ hodnoty a důstojnosti všech lidí. ${ }^{15}$ Otázkou tedy je, zda lidská práva můžeme považovat za profesní hodnotu sociální práce. Pokud se přikloníme k vymezení pojmu hodnota na základě jejích vlastností, jeden $\mathrm{z}$ atributů hodnoty, její univerzálnost, hodnotu řadí nad normy a principy. ${ }^{16}$ Proto by i lidská práva měla představovat spíše soubor principů, které nejsou označovány za profesní hodnotu, ale $\mathrm{z}$ hodnot vycházejí. Mluvit tedy v kruhu sociálních pracovníků o profesních hodnotách bez shodného předporozumění pojmu hodnota se zdá jako déle neudržitelné. Rovněž již v sociální práci nevystačíme pouze s definicí hodnoty, která by měla představovat „to, co daná společnost nebo jednotlivec považují za žádoucí, vhodné a dobré - o co usilují" ${ }^{17}$ Přestože se v sociální práci necháváme inspirovat nebo přejímáme některé informace z př́ibuzných oborů, potřebujeme $\mathrm{v}$ profesi sami definovat hodnotu nikoli jako „obecný pojem pro

13 Srov. např. Panajotis CAKIRPALOGLU, Psychologie bodnot, Olomouc: Votobia, 2004; Ivan BLECHA a kol., Filosofický slovník, Olomouc: Nakladatelství Olomouc, 1998, s. 171; Pavel KLENER - Miloslav PETRUSEK, Velký sociologický slovník I, Praha:

Karolinum, 1996, s. 375-377.

14 Srov. Tomáš MACHULA - Helena MACHULOVÁ, Nedostatečná definice pojmu hodnota jako zásadní problém etiky sociální práce, Sociální práce / Sociálna práca 1/2009, s. 97-104.

15 Srov. (C) Společnost sociálních pracovníků ČR, Etika sociální práce-principy, čl. 4.

16 Srov. Panajotis CAKIRPALOGLU, Psychologie hodnot, s. 364.

17 Oldřich MATOUŠEK, Slovník sociální práce, s. 77. 
všechno, čeho si ceníme nebo vážíme “. ${ }^{18}$ Záměrem vlastního vymezení pojmu hodnota by měla být především snaha budovat vlastní sebe-pojetí, identitu, s cílem strukturovat pozici hodnot v hierarchii profesních principů, cílů či metod, aby se tím upevňovala stabilita profese, která se právě odvijí také od stanovených pevných základů (poslání, hodnot aj.) spolu s utvořením hierarchie mezi nimi. ${ }^{19}$

\section{Pluralita profesních hodnot}

Při takovémto postupu však dříve či později dospějeme k tvrzení, že sociální práci nikdy nelze plně oddělit od jejího sociálního prostředí, ve kterém je uskutečňována, protože odpovídá na jeho specifické potřeby. Sociální práce je tedy specifická $\mathrm{v}$ tom, že $\mathrm{v}$ souvislosti s růzností potřeb, kultur, myšlení, vlivu náboženství apod. se částečně mění pohled na postavení jednotlivých profesních hodnot v sociální práci. ${ }^{20}$ Hodnotový pluralismus proto nemůžeme vnímat pouze negativně. Sociální práce, odpovídající na aktuální sociální problémy své doby a ve svém prostředí, potřebuje být ze své podstaty také částečně flexibilní a různorodá, protože „př́lišná uzavřenost a ohraničenost profese vytváŕí sice stabilitu (at' už striktně definovanými a dodržovanými hodnotami), ale neumožňuje růst, vývoj a kreativitu“. ${ }^{21}$ Banksová nadto upozorňuje, že jednotně definované hodnoty by byly ovlivněné především západoevropskou kulturou a myšlením, která však nezahrnuje celé spektrum sociální práce a nemusí být objektivně nejvhodnější pro sociální práci v celém jejím rozsahu. ${ }^{22}$ Naopak ale př́lišná otevřenost a neohraničenost profese ( $\mathrm{tj}$. i v rámci definovaných hodnot) vede $\mathrm{k}$ její nejasné identitě až k „roztřřšstěnosti“. ${ }^{23}$

Částečné řešení sporu mezi na jedné straně striktně danými profesními hodnotami a na straně druhé profesními hodnotami definovanými pouze $\mathrm{v}$ rámci jednotlivých organizací, sdružení, států, v závislosti na specifikách vlastní kultury i politiky, mohou nabízet právě etické kodexy profese na mezinárodní úrovni. Aktuálně je v Mezinárodním kodexu (pouze) členským organizacím ukládána „...povinnost rozvíjet a pravidelně aktualizovat svoje vlastní etické normy nebo etické směrnice tak, aby byly konzistentní s prohlášením“" ${ }^{24}$ Mezinárodní federace sociálních pracovníků. Mezinárodní etický kodex zároveň předpokládá, že profesní hodnoty jmenované $\mathrm{v}$ kodexu budou rozpracovány dle vlastních specifik, přesto $s$ ním zůstanou v souladu.$^{25}$ Nicméně v jednotlivých kodexech členských zemí, asociací i organizací často postrádáme spojitost či jakýkoli odkaz na stanovené mezinárodní profesní hodnoty. ${ }^{26}$ Otázkou je, do jaké míry je důležitým faktorem nejednoznačnost hodnot či do jaké míry se zde také projevuje nedostatečná angažovanost a nekomunikace mezi sociálními pracovníky na mezinárodní úrovni.

18 Radoslav GOLDMANN - Martina CICHÁ, Etika zdravotní a sociální práce, Olomouc: Univerzita Palackého, 2004 , s. 8.

19 Srov. Monika FLÍDROVÁ - Michal OPATRNÝ, Role hodnot v identitě sociální práce, s. 125.

20 Srov. Payne in Oldřich MATOUŠEK, Úvod: Cíle a úrovně sociální práce, in: Metody a ř́íení sociálnípráce, ed. Oldřich

MATOUŠEK, Praha: Portál, 2013, s. 12.

21 Monika FLÍDROVÁ - Michal OPATRNÝ, Role hodnot v identitě sociální práce, s. 125.

22 Srov. Sarah BANKS, The social work value base, s. 32.

23 Srov. Libor MUSIL, Různorodost pojetí, nejasná nabídka a kontrola výkonu „sociální práce“, Sociální práce / Sociálna práca 2/2008, s. 83-84.

24 Srov. (C) Společnost sociálních pracovníků ČR, Etika sociální práce-principy, čl. 5.

25 Srov. tamtéž.

26 Souhrnnému srovnání etických kodexů různých zemí se již věnovala S. Banks (srov. Sarah BANKS, Etbics and Values in Social Work, Londýn: Macmillan Press, 1995, s. 91-102). 
Přesto tato specifikace hodnot může umožnit sociálním pracovníkům pochopit jejich význam i jejich propojenís posláním profese či organizace. Proto může být proces aplikace profesních hodnot velkou měrou ovlivněn strategií řízení organizace. ${ }^{27}$ Interpretace definovaných hodnot se objevuje četně $\mathrm{v}$ zahraniční i české literatuře (viz úvod). Jakési souhrnné rozpracování některých hodnot nalezneme např. v Encyklopedii sociální práce, ve které jsou tyto hodnoty představeny spíše ve svém historickém kontextu západoevropského myšlení. Autoři při jejich definování čerpají z politologie, sociologie, filosofie či etiky. Nedostatečně však zpracovávají jednotlivé hodnoty v kontextu praxe, principů a cílů sociální práce. ${ }^{28}$ K průběžné aktualizaci a interpretaci profesních hodnot u nás dochází často až v konfrontaci s opozičním postojem. Vzpomeňme např. širokou diskuzi, která u nás nastala po zveřejnění článku M. Mitlöhnera Kprávním a etickým problémuim spojeným snarozením tě̌̌ce malformovanébo jedince, ${ }^{29}$ jehož odlišné pojetí lidství, důstojnosti, svobody či smyslu života vedlo v mnohém $\mathrm{k}$ otevření debaty o hodnotách. ${ }^{30}$

\section{Střet osobních hodnot s profesními}

Přesto právě povinností profesní etiky je neustále reagovat, odpovídat, obhajovat či aktualizovat své hodnotové pojetí. Avšak proti nadměrné snaze pevně definovat a aplikovat profesní hodnoty v sociální práci stojí v opozici důraz na svědomí a vlastní etické jednání sociálních pracovníků na základě osobních hodnot. ${ }^{31}$ Proto ani „kodex nemůže být přesnou kuchařkou, podle níž by sociální pracovník bezmyšlenkovitě jednal - neměl by pak prostor pro vlastní úsudek a rozhodování a etická dimenze by se z jeho jednání nutně vytratila“. ${ }^{32}$ Osobní hodnoty pak zabraňují sociálnímu pracovníkovi přistupovat k profesi mechanicky, ale umožňují vnímat ji jako osobní poslání a vytvářet vztahy s klienty, které jsou založené na principu opravdovosti, empatickém porozumění či upř́mnosti. Velká část výzkumů o hodnotách $\mathrm{v}$ sociální práci se proto zaměřuje právě na osobní hodnoty sociálních pracovníků, protože se obecně má za to, že právě ony mají primární vliv na jeho vztah ke klientovi, užité metody intervence a pracovní postupy.

Promítání osobních hodnot do profesních vizí však může být problematické. Hodnoty obecně představují ideál, univerzální představu o tom, co je žádoucí (viz bod 2). Přestože sociální práce nevylučuje osobní hodnotové a etické orientace pracovníka př̀ řešení situací,

\footnotetext{
27 Jeden ze způsobů aplikace hodnot v organizaci uvádí P. Vrzáček. Ve svém návrhu, který vychází z praxe Domova seniorů v Lanškrouně, přisuzuje organizaci moc postihovat a kontrolovat jednání sociálních pracovníků na základě hodnot: „Organizace musí mít formulovanou vizi a hodnoty, které naplňování vize umožňují. Mezi organizační vizí a hodnotami přitom musí existovat vazba. Organizační hodnoty musí být definovány v interní dokumentaci, a ta musí být v různých formách př́stupná všem zaměstnancům. Zaměstnanci organizační hodnoty musí znát a musí být schopni plnit své pracovní povinnosti v souladu s organizačními hodnotami. Zaměstnanci, kteří se při výkonu práce drží organizačních hodnot, musí být za tuto činnost odměňováni. Zaměstnanci, kteří se organizačními hodnotami neřídí, naopak trestáni. Dohled nad dodržováním organizačních hodnot musí mít všichni zaměstnanci, zvláště pak zaměstnanci působící na manažerských pozicích. Řešení konfliktních situací přísluší manažerům. "Petr VRZÁČEK, Vedení ve shodě s organizačními hodnotami, in: Hodnoty v prostredí sociálních a zdravotních sluǧeb, ed. Zuzana HAVRDOVÁ, Praha: Fakulta humanitních studií Univerzity Karlovy, 2010, s. 189-190.

28 Srov. např. Alois KŘIŠŤAN, Humanita; Tomáš MACHULA, Solidarita; Tomáš MACHULA, Důstojnost; Eva DRAGOMIRECKÁ, Kvalita života, in: Encyklopedie sociální práce, ed. Oldřich MATOUŠEK, Praha: Portál, 2013, s. 201-206, 223-226.

29 Srov. Miroslav MITLÖHNER, K právním a etickým problémům spojeným s narozením těžce malformovaného jedince, Časopis żdravotnickébo práva a bioetiky 1/2014, s. 48-54.

30 Do této diskuse se tematicky zapojil i časopis Caritas et veritas (1/2015) vydávaný Teologickou fakultou Jihočeské univerzity.

Toto číslo neslo název Právo na život a jeho články odkazovaly př́ímo či nepř́ímo právě na Mitlöhnerův text.

31 Srov. Frederic G. REAMER, Social work values and etbics, New York: Columbia university press, 1999, s. 28.

32 Mirka NEČASOVÁ, Profesní etika, s. 42.
} 
kterými se zabývali např. Reamer ${ }^{33}$ nebo Musil, ${ }^{34}$ ba právě tyto ovlivňují především praxi, připojmenovánízákladních profesních hodnotnelzevycházetpouzezvlastních hodnotových orientací sociálních pracovníků a jejich profesního pojetí. Jednotlivé typy profesního pojetí Reamera či Musila totiž představují spíše soubor charakteristik typů sociálních pracovníků, tj. toho, jaký „materiál“" v sociální práci skutečně je k dispozici. Pak by ale podle výzkumu (viz bod 1) měla být hlavní hodnotou sociální práce empatie, která ovšem nepředstavuje žádný profesní ideál, je obvykle označována pouze jako vhodná komunikační dovednost, na jejímž základě se např. utváří vztah mezi sociálním pracovníkem a klientem. ${ }^{35}$ Hodnoty mají být ale úzce propojeny s profesní vizí, ${ }^{36}$ vztahují se ke smyslu a poslání sociální práce. Přesto však osobní hodnoty mají vliv na samotný výběr profese sociální práce. Hartl uvádí, že by měl mít „základní rysy osobnosti sociálního pracovníka“ každý, kdo se chce této profesi věnovat, již před nastoupením do vzdělávacího a poté pracovního procesu, ve kterém je pracovník odpovědný a povinný jednat podle profesních i specifických organizačních hodnot, pokud jsou organizací dány. At už je tedy sociální pracovník motivován různými hodnotami, měl by především umět tyto hodnoty reflektovat, tj. uvědomovat si, jakým způsobem ovlivňují jeho činnost, a využít toho k úsilí o změnu k lepšímu. ${ }^{37}$

Sociální pracovník „zároveň musí počítat s tím, že se ocitne v tenzi mezi svými osobními hodnotami a hodnotami klienta, svého zaměstnavatele a vůbec celé profese sociální práce. Tak vznikají určité konflikty hodnot, " ${ }^{38}$ jejichž př́činou je střet hodnot při řešení konkrétního problému. Také se může dostat do konfliktu s typem organizačního vedení, zejména v těch organizacích, v nichž je kladen důraz na pravidla, která jsou jasně vymezena, a je jasně určená hierarchie spolu s pravomocemi jednotlivých pracovníků: „Sociální pracovníci zaměstnaní $\mathrm{v}$,mechanických byrokratických organizacích mají menší možnost profesní autonomie než jejich kolegové, kteří pracují v menších nezávislých, příp. nestátních organizacích. Mají také k dispozici menší prostor pro udržení etického kodexu jako primárního závazku profese. “39Avšak podle českého kodexu by měl zaměstnavatel vytvářet „takové podmínky, které umožní sociálním pracovníkům v ní zaměstnaným přijmout a uplatňovat závazky, vyplývající z tohoto kodexu“."40

\section{Závěrem}

Schopnost autonomního jednání sociálního pracovníka vychází z vytvoření si pevné vlastní identity na základě poznání sebe sama a ztotožnění se s profesní identitou či posláním organizace. Všechny výše zmíněné aspekty pak více či méně ovlivňují možnosti sociálních

33 Reamer pojmenoval šest modelů etických orientací sociálních pracovníků, které se objevovaly v průběhu vývoje sociální péče a jsou vedle sebe prítomné dodnes. Srov. Frederic G. REAMER, Social work values and etbics, s. 17-18.

34 Musil specifikoval čtyři pojetí sociální práce (administrativní, filantropické, profesionální, aktivistické) především na základě svého výzkumu se sociálními pracovníky, zkoumání jejich hodnotových orientací a představ o profesi. Srov. Libor MUSIL,

Různorodost pojetí, nejasná nabídka a kontrola výkonu „sociální práce“; Daniela RŮŽIČKOVÁ - Libor MUSIL, Hledají sociální pracovníci kolektivní identitu?, Sociální práce /Sociálna práca 3/2009, s. 79-92.

35 Srov. Oldřich MATOUŠEK - Pavel HARTL, Nároky sociální práce a syndrom vyhoření, in: Metody a ř́żení sociální práce,

ed. Oldřich MATOUŠEK, Praha: Portál, 2013, s. 51-52.

36 Srov. Petr VRZÁČEK, Vedení ve shodě s organizačními hodnotami, s. 189-190.

37 Srov. Pavel HARTL, Poradenství, in: Metody a ř́renení sociální práce, ed. Oldřich MATOUŠEK, Praha: Portál, 2013 , s. 111.

38 Monika FLÍDROVÁ - Michal OPATRNÝ, Role hodnot v identitě sociální práce, s. 122.

39 Mirka NEČASOVÁ, Profesní etika, s. 43.

40 (C) Společnost sociálních pracovníků ČR, Etický kodex společnosti sociálních pracovníkủ ČR, čl. 2.2.2. 
pracovníků interiorizovat profesní hodnoty (a spolu s tím poslání profese či organizace) a řídit se podle nich ve své praxi. Sociální pracovník je tak nucen spíše jednat intuitivně, řídit se svými hodnotami, které zaměňuje za profesní hodnoty, nebo se stylizuje do pozice spíše administrativního pracovníka. Přesto Mezinárodní kodex přenáší zodpovědnost etického jednání na pracovníky, kteří se zaručují, „že jejich rozhodnutí budou eticky podložená“. ${ }^{41}$ Problémem je, že v žádném $\mathrm{z}$ etických kodexů se asociace nezamýšlejí nad tím, že se pracovníkovi nedaří stanovené hodnoty dodržovat. Proto nejen do Etického kodexu společnosti sociálních pracovníků ČR by bylo vhodné nově začlenit některé zásady vztahu sociálního pracovníka k profesním hodnotám, ale i zdůraznit vlastní reflexi. Pomáhající by měl být dle Kopřivy „připraven kdykoliv vnímat a akceptovat svou nedokonalost, slabost a zranitelnost, kterou pomáhání vyjevuje, a pomocí sebereflexe a supervize napomáhat vývoji k lepšímu stavu, než je ten současný “. ${ }^{42}$

\title{
Problematika aplikace profesních hodnot v sociální práci
}

\begin{abstract}
Abstrakt
Článek vychází z reflexe výzkumu Grantové agentury Jihočeské univerzity č. 117/2013/H, jehož součástí bylo také téma profesních hodnot. Výsledky dotazníkového šetření výzkumu upozorňují na problematiku aplikace profesních hodnot v sociální práci. Cílem článku je primárně poukázat na některéz bariér v aplikaci hodnot, souvisejících především s definováním pojmu hodnota a pluralitou hodnot v sociální práci. Studie vychází z obecného pojetí, že se sociální pracovník potřebuje ve své praxi rrídit také hodnotami, které vedou k naplňování poslání a smyslu sociální práce.
\end{abstract}

Klíčová slova: sociální práce, hodnota, profesní hodnoty, aplikace hodnot

\section{The Issue of Applying Professional Values in Social Work}

\begin{abstract}
The article is based on reflecting the research of Grant Agency of the University of South Bohemia no. $117 / 2013 / \mathrm{H}$, part of which was also the topic of professional values. The results of the survey research draw attention to the issue of applying professional values in social work. This article aims primarily to highlight some of the barriers to value application, mainly related to the definition of the concept of values and to the plurality of values in social work. It is based on the general notion that in their practice social workers need to follow values leading to fulfilling the mission and purpose of social work.
\end{abstract}

Keywords: social work, value, professional values, applying values

41 (C) Společnost sociálních pracovníků ČR, Etika sociálnípráce - principy, čl. 5.

42 Karel KOPŘIVA, Lidský vætab jako sončást profese: Psychoterapentické kapitoly pro sociální, pedagogické a zdravotnické profese, Praha: Portál, 1997, s. 91. 
$161 \frac{5}{2015}$

\section{Kontakt na autora}

\section{Mgr. Bc. Monika Flídrová}

Jihočeská univerzita v Českých Budějovicích

Teologická fakulta, Katedra etiky, psychologie a charitativní práce

Kněžská 8, 37001 České Budějovice

monikaflidrova@seznam.cz 